\title{
SPECTROSCOPIC STUDIES OF SELF-ASSEMBLED TPPS 4 NANOSTRUCTURES IN AQUEOUS SOLUTIONS: THE ROLE OF SERUM ALBUMIN AND pH
}

\author{
J. Valančiūnaitė, J. Žerebcova, S. Bagdonas, G. Streckytè, and R. Rotomskis \\ Laser Research Centre, Vilnius University, Saulètekio 9, LT-10222 Vilnius, Lithuania
}

Received 18 November 2003

\begin{abstract}
The interaction of meso-tetra(4-sulphonatophenyl) porphyrin (TPPS 4 ) with bovine serum albumin (BSA) in acid medium was investigated using optical absorption spectroscopy. Changes in the absorption spectra indicate that a mechanism of interaction between TPPS $_{4}$ and BSA is in a complex manner dependent on: (a) the ratio between monomeric and aggregated species in a homogenous solution of TPPS 4 , (b) the molar ratio of the TPPS 4 -BSA mixture, and (c) the initial state of protein solution. When different forms of TPPS 4 exist in solution, small relative concentrations of BSA favour J-aggregation; however, higher concentrations may lead to the disruption of J-aggregates. If J-aggregates are preformed in the solution, adding of protein does not disrupt these aggregates.
\end{abstract}

Keywords: absorption spectroscopy, $\mathrm{TPPS}_{4}$, J-aggregates, self-assembling, albumin, $\mathrm{pH}$

PACS: $33.20 . \mathrm{Kf}, 33.20 . \mathrm{Lg}$

\section{Introduction}

Water-soluble porphyrins and porphyrin derivatives are well established photosensitizers for photodynamic therapy (PDT) of cancer. The efficiency of PDT is highly dependent on the photophysical properties of the sensitizers, such as their intensive absorbance in the far red spectral region and high quantum yields for triplet state population and singlet oxygen generation. However, these properties can vary with the aggregation state of the porphyrins [1-7].

The interaction with different macromolecules and other biological structures can also affect the photodynamic efficacy of porphyrins [8-10]. The changes in photophysical properties of meso-tetra(4-sulphonatophenyl) porphyrin $\left(\mathrm{TPPS}_{4}\right.$ ) upon binding to human serum albumin (HSA) were investigated and some of them were attributed to the ability of the protein to monomerize aggregates of the sensitizer [11].

In aqueous media TPPS $_{4}$ molecules exist in different ionic forms, depending on medium acidity. In very acidic solutions $(\mathrm{pH}<2)$, where the diprotonated form $\left(\left(\mathrm{H}^{+}\right)_{2} \mathrm{TPPS}_{4}\right)$ prevails, these ionic species start forming one-dimensional ordered arrangements, called J-aggregates $[12,13]$. Strong interaction between the molecules within the J-aggregate leads to collective effects in the optical response: an exciton band (J-band) is formed. In pure solutions the formation of $\mathrm{J}$-aggregates is initiated by the increase of concentration, medium acidity or ionic strength. Formation of J-aggregates could also be promoted by interaction with surfactants [14] and proteins [15]. Due to these unique optical properties determined by selforganization of the molecules, the special interest in J-aggregates of TPPS 4 arises.

It has been shown that $\mathrm{TPPS}_{4}$ localizes mainly in lysosomes when being introduced into the organism [16]. The lumen of these organelles is acid ( $\mathrm{pH}$ 4.6-4.8). Under such acidity, the diprotonated form of TPPS $_{4}$ is present in aqueous media. Therefore, the possibility cannot be ruled out that $\mathrm{TPPS}_{4}$ can probably form $\mathrm{J}$-aggregates when being accumulated in cells as well.

Another field of application for organic materials, such as porphyrins, is the development of new nanodevices through the self-assembly, which occurs in nature, but might also be useful in designing supramolecular structures with suitable properties. Self-assembly provides a primary mechanism through which molecular aggregate structures in both natural and artificial systems are created. The manipulation with selfassembled structures could be an alternative method for nanofabrication techniques. The adsorption of such self-assembled structures on solid surfaces is one 


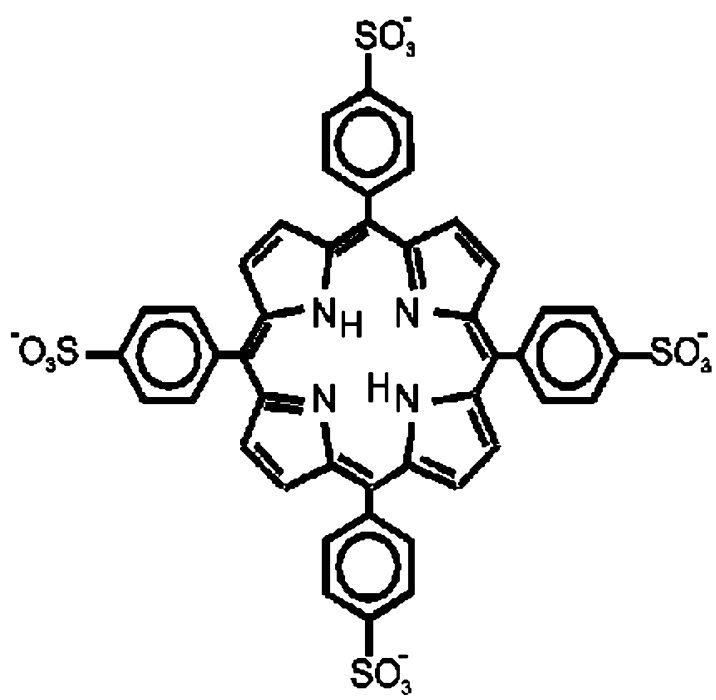

(a)

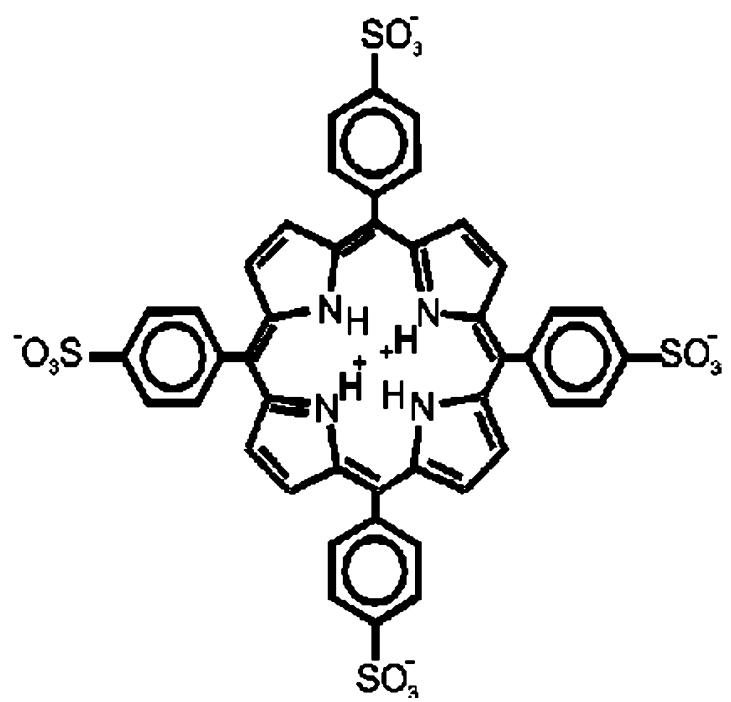

(b)

Fig. 1. (a) Deprotonated and (b) protonated forms of $\mathrm{TPPS}_{4}$.

of the fundamental processes for the development of molecule-based nanodevices.

Presuming that the J-aggregates can be formed in biological media, the method of absorption spectroscopy was applied to investigate the influence of the bovine serum albumin on the formation of J-aggregates.

\section{Materials and methods}

$\mathrm{TPPS}_{4}$ was obtained from Porphyrin Products (Logan, Utah, USA) and bovine serum albumin (BSA) from Fluka (USA). Solutions of $\mathrm{TPPS}_{4}$ and BSA were prepared in distilled water. Medium $\mathrm{pH}$ was varied by adding appropriate amounts of $0.1 \mathrm{M} \mathrm{HCl}$. For the interaction studies, TPPS $_{4}$ concentration was kept constant, while the BSA concentration was varied. Equal volume parts of TPPS 4 and BSA solutions were mixed before the spectroscopic measurements.

The $\mathrm{pH}$ values of $\mathrm{TPPS}_{4}$-BSA solutions were controlled using a $\mathrm{pH}-$ meter IC150 (IQ Scientific Instruments, Inc., USA) with glass electrode CW711.

Absorption measurements were performed by the fibre optics built-in spectrometer PC1000 (Ocean Optics Inc., USA) using $1 \mathrm{~mm}$ and $10 \mathrm{~mm}$ optical path quartz cuvettes.

\section{Results}

In neutral and basic aqueous media, TPPS $_{4}$ molecules exist in a nonprotonated form (Fig. 1(a)). The absorption spectrum of the nonprotonated form consists of the Soret band with a peak at around $412 \mathrm{~nm}$ and four

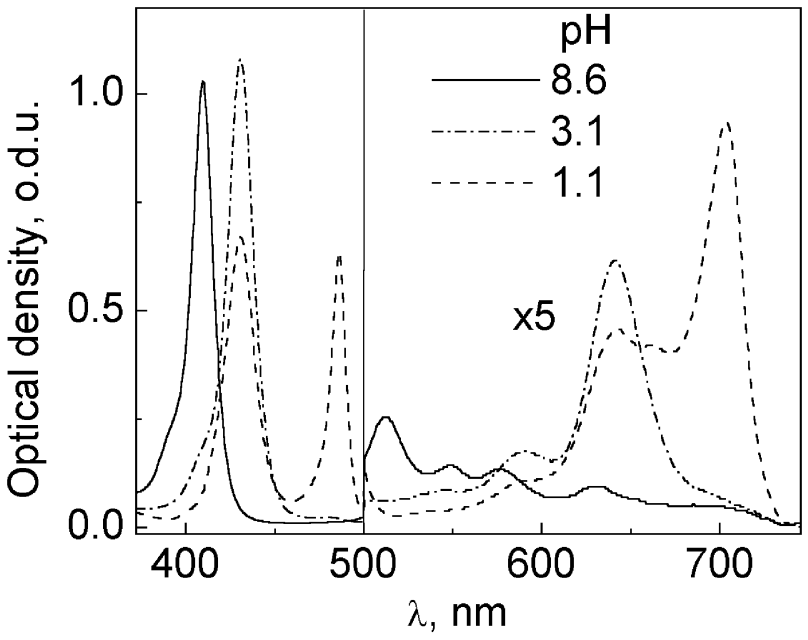

Fig. 2. Changes in the absorption spectra of $\operatorname{TPPS}_{4}\left(c=7 \cdot 10^{-6} \mathrm{M}\right)$ occurring upon increase in acidity of the medium.

Q absorption bands in the visible spectral region, which is typical of the etio-type spectra (Fig. 2). When acidity of the aqueous medium increases, the protonated form of $\mathrm{TPPS}_{4}$ (Fig. 1(b)) becomes dominant. At that time new absorption bands can be observed at $433 \mathrm{~nm}$ and also at 592 and $645 \mathrm{~nm}$ (Fig. 2). In very acidic media two new absorption bands are formed at 488 and $706 \mathrm{~nm}$ (Fig. 2), which are typical of the J-aggregates of $\mathrm{TPPS}_{4}$ [17].

An aqueous solution of bovine serum albumin was chosen as a model of a biological system for the interaction studies. The preliminary studies of $\mathrm{pH}$ influence on absorbance of pure BSA solutions showed that absorption spectrum of the albumin did not overlap with the absorption bands of both the nonproto- 


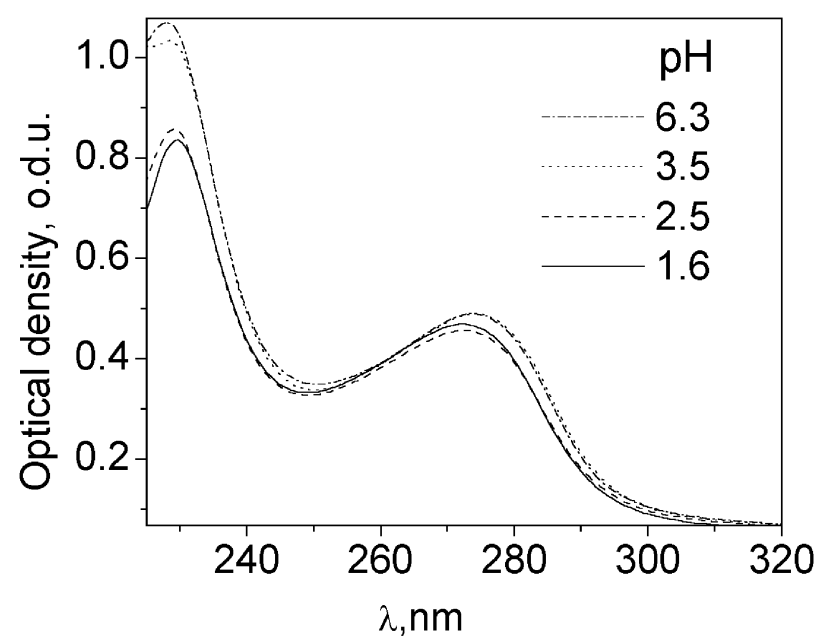

Fig. 3. Absorption spectra of BSA $\left(c=10^{-5} \mathrm{M}\right)$ in homogeneous solution of different acidity.

nated and protonated forms of TPPS 4 . Changing the medium acidity the absorbance of BSA changed only very slightly (Fig. 3).

Two different concentrations of $\mathrm{TPPS}_{4}$ were chosen for the interaction studies in the acid medium. In the absence of BSA (the $\mathrm{TPPS}_{4}$ :BSA molar ratio 1:0) in acid aqueous solution at lower porphyrin concentration $\left(5 \cdot 10^{-6} \mathrm{M}\right)$, the absorption bands of monomeric $\left(\mathrm{H}^{+}\right)_{2}$ TPPS $_{4}$ at 433 and $645 \mathrm{~nm}$ dominated in the spectrum (Fig. 4(a)). The intensity of the absorption bands of J-aggregates at 487 and $705 \mathrm{~nm}$ was very low. The presence of even relatively small amount of BSA in the solution $\left(\mathrm{TPPS}_{4}\right.$ : BSA of $\left.1: 0.005\right)$ induced significant decrease of monomer bands and increase of J-aggregate bands. When the molar ratio $\mathrm{TPPS}_{4}$ : BSA was further increased from $1: 0.005$ to $1: 0.1$, the absorption bands of J-aggregates became even more intense and underwent a slight blue shift to 484 and $702 \mathrm{~nm}$. The maximal absorption intensity of J-aggregates in the solution was observed when the molar ratio was about $1: 0.1$. On the other hand, the Soret band underwent further decrease in intensity with simultaneous broadening and a blue shift. When the ratio TPPS $_{4}$ :BSA in the complex solution was $1: 2$, the intensity of the excitonic band of $\mathrm{J}$-aggregates decreased and its peak underwent a small bathochromic shift. A new peak of the Soret band formed at around $421 \mathrm{~nm}$. The intensity of this peak increased with the increase of protein concentration. Narrowing of the absorption band of J-aggregates in the far-red spectral region was observed together with the formation of two flat peaks in the region of $500-550 \mathrm{~nm}$.

At higher concentration of $\mathrm{TPPS}_{4}\left(5 \cdot 10^{-5} \mathrm{M}\right)$ the absorption bands of J-aggregates dominated in the spec-

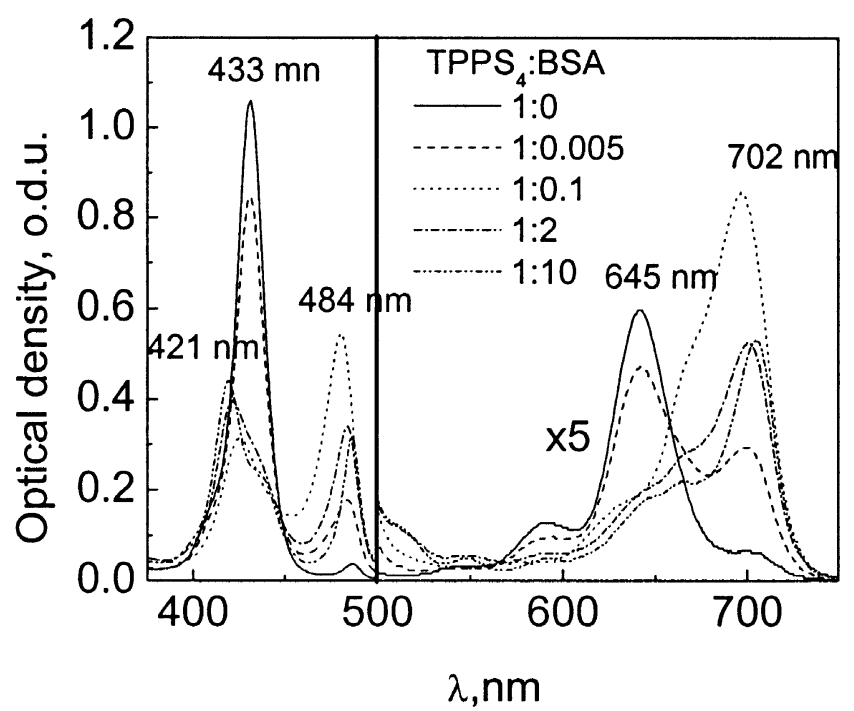

(a)

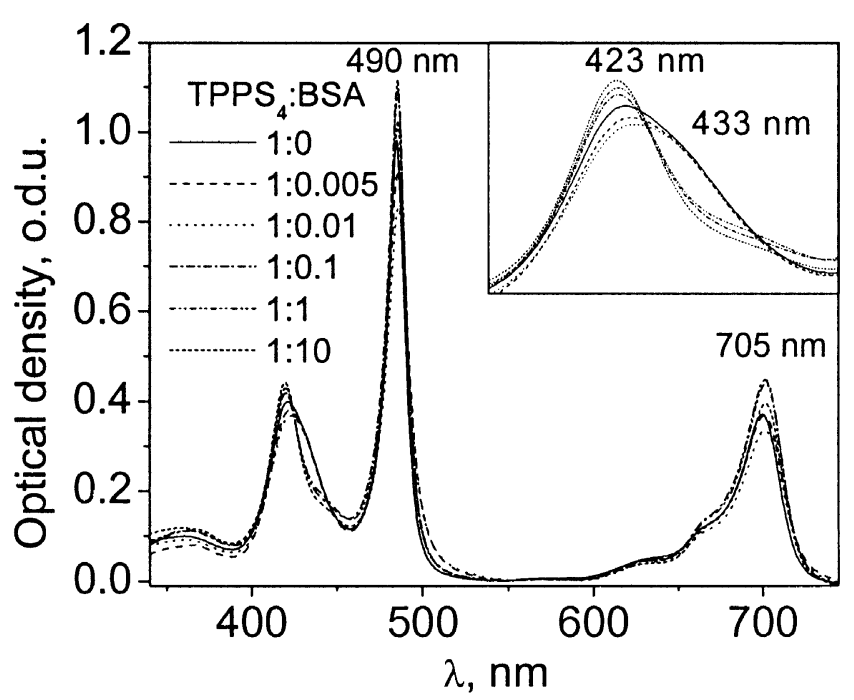

(b)

Fig. 4. Absorption spectra of $\mathrm{TPPS}_{4}\left((\mathrm{a}) c=5 \cdot 10^{-6} \mathrm{M}\right.$, (b) $c=$ $5 \cdot 10^{-5} \mathrm{M}$ ) when the molar ratio of $\mathrm{TPPS}_{4}$ to BSA in the solution changes from $1: 0.005$ to $1: 10(\mathrm{pH}=1.2)$.

trum of the pure solution (Fig. 4(b)). Instead of the Soret band of the monomeric $\left(\mathrm{H}^{+}\right)_{2} \mathrm{TPPS}_{4}$, the broad Soret band was observed at around $426 \mathrm{~nm}$ with a shoulder on the long-wave side. The intensity of the Soret band slightly decreased at $\mathrm{TPPS}_{4}$ : BSA molar ratios from $1: 0.005$ to $1: 0.01$ and the formation of pellet in the complex solution was observed immediately after mixing. No pellet was formed at higher BSA concentrations, probably due to the enhanced solubility of J-aggregates. The changes in the shape of the Soret band (a hypsochromic shift and narrowing, Fig. 4(b)) as well as slight increase in intensity were found to be similar to those observed in the case of lower concentration of $\mathrm{TPPS}_{4}$ (Fig. 4(a)). Increase of $\mathrm{TPPS}_{4}$ :BSA 
$\mathrm{TPPS}_{4}$ in $\mathrm{H}_{2} \mathrm{O} / \mathrm{BSA}$ in $\mathrm{HCl}, \mathrm{pH}=1.6$

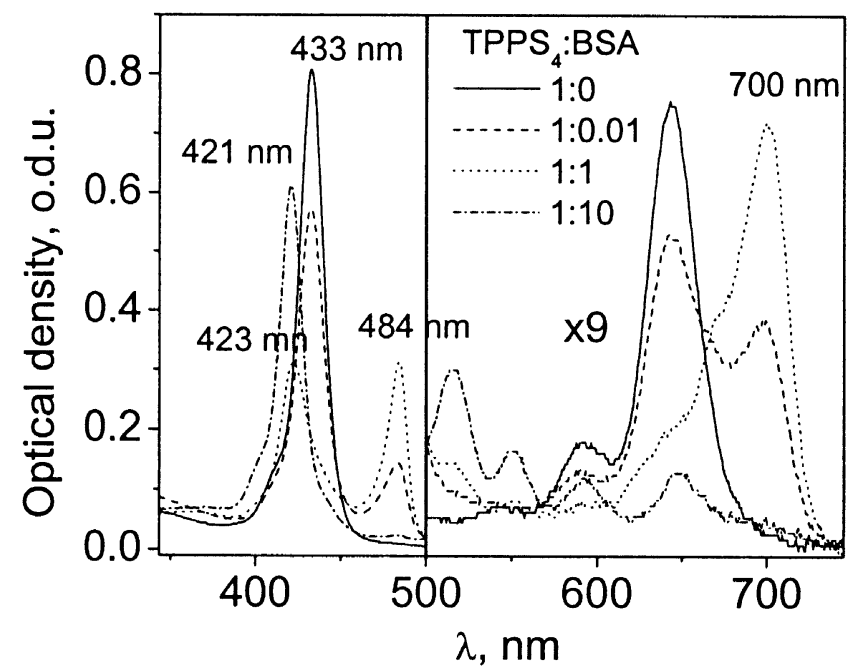

(a)

$\mathrm{TPPS}_{4}$ in $\mathrm{HCl} / \mathrm{BSA}$ in $\mathrm{H}_{2} \mathrm{O}, \mathrm{pH}=1.4$

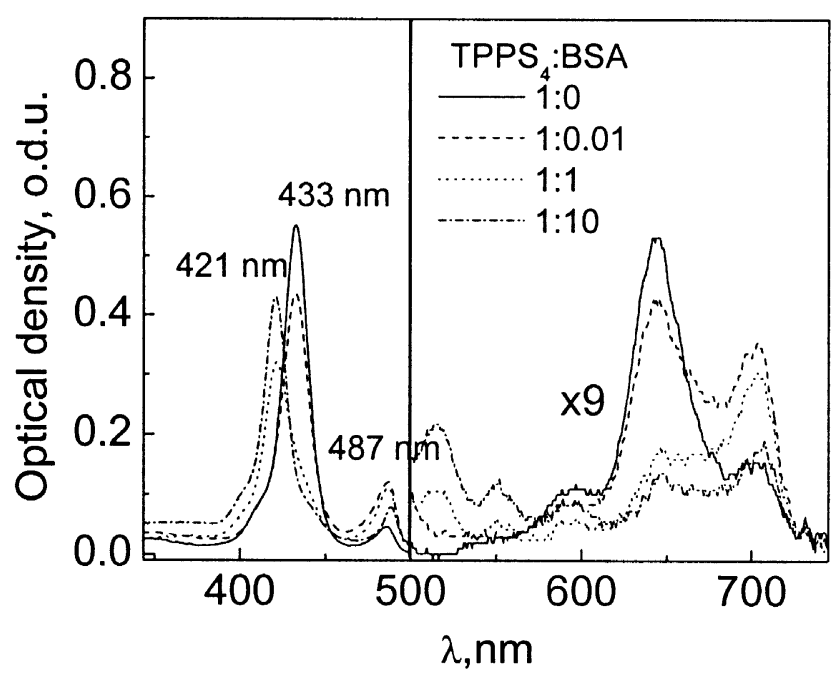

(c)
$\mathrm{TPPS}_{4}$ in $\mathrm{HCl} / \mathrm{BSA}$ in $\mathrm{HCl}, \mathrm{pH}=1.3$

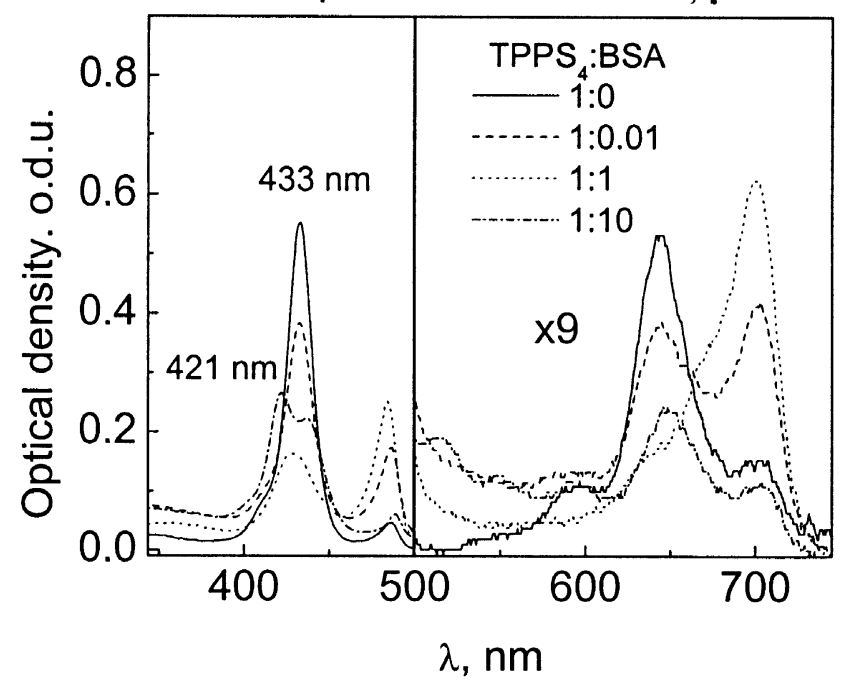

(b)

TPPS $_{4}$ in $\mathrm{H}_{2} \mathrm{O} / \mathrm{BSA}$ in $\mathrm{H}_{2} \mathrm{O}, \mathrm{pH}=5.6$

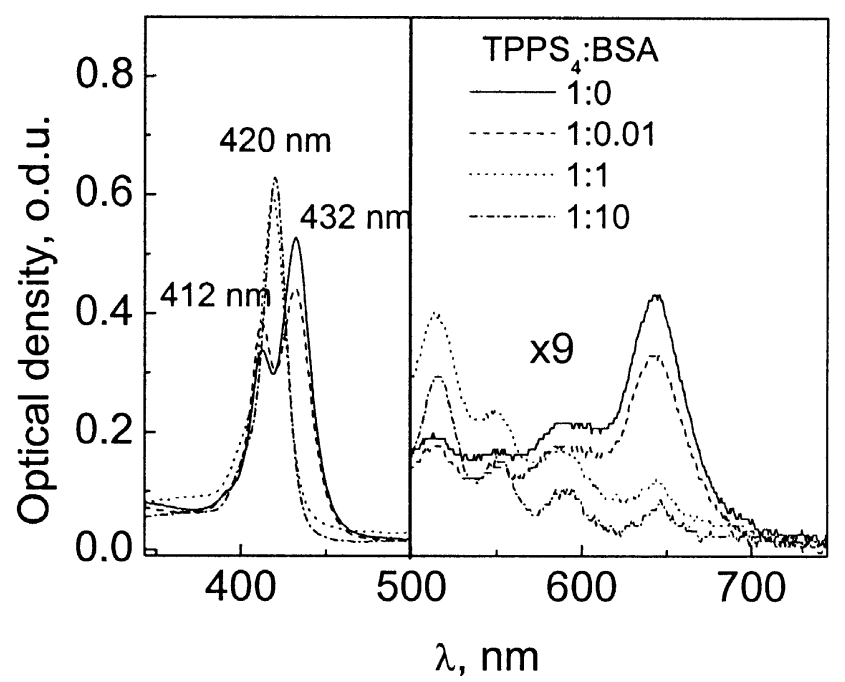

(d)

Fig. 5. Spectral changes occurring in the mixed solutions during the interaction between $\operatorname{TPPS}_{4}\left(c=2 \cdot 10^{-6} \mathrm{M}\right)$ and BSA.

molar ratios up to $1: 10$ resulted in slight decrease of J-aggregate absorption bands at 490 and $705 \mathrm{~nm}$.

To get more detailed information on how BSA influences the formation of J-aggregates, the role of the initial states of both components during the interaction was investigated. For this, pure solutions of $\mathrm{TPPS}_{4}$ and BSA were made in distilled water and also in $0.1 \mathrm{M}$ $\mathrm{HCl}$. The complex solutions were prepared by mixing equal volumes of both components to get different $\mathrm{TPPS}_{4}$ :BSA molar ratios, and their spectra are presented in Fig. 5. Figure 5(a) reflects the spectral changes observed when increasing amounts of BSA (dissolved in acid) were mixed with the $\mathrm{TPPS}_{4}$ (dissolved in distilled water). Similarly as in Fig. 4(a), the shape of the absorption spectrum of pure TPPS $_{4}$ at concentration $2 \cdot 10^{-6} \mathrm{M}$ was characteristic of monomeric $\left(\mathrm{H}^{+}\right)_{2}$ TPPS $_{4}$ species (Fig. 5(a), solid line). However, at this concentration no J-aggregates were observed. Formation of J-aggregates (a new band at $484 \mathrm{~nm}$ ) was induced by the presence of BSA at molar ratios up to $1: 1$. The narrow Soret band at $421 \mathrm{~nm}$, absent J-aggregate bands, and an etio-type spectrum in the visible region were characteristic features of the solutions at the molar ratio $1: 10$.

In the complex solutions, where both components were predissolved in $0.1 \mathrm{M} \mathrm{HCl}$, the smaller amount of J-aggregates formed at the molar ratio $1: 1$ (Fig. 5(b), dotted line). At higher molar ratio $(1: 10)$ the intensity 
of J-aggregate band decayed almost to the initial value observed in the pure solution (dashed-dotted and solid lines, respectively). The Soret band at $421 \mathrm{~nm}$ exhibited a second peak at around $436 \mathrm{~nm}$. Five broad bands comprised the spectrum in the visible spectral region.

In contrast to the both previous cases, the highest amount of J-aggregates formed at the smallest molar ratio $(1: 0.01)$ in complex mixtures prepared by adding BSA dissolved in distilled water (Fig. 5(c)). At the molar ratio $1: 10$, the Soret band resembled that of Fig. 5(a) in shape, while the bands in the visible spectral region were similar to those in Fig. 5(b) (dasheddotted lines). Similarly as in Fig. 5(b), J-aggregates were present even at the highest protein ratio.

Spectral changes observed in the complex mixtures in distilled water reflected the strong interaction between diprotonated species of porphyrin and BSA (Fig. 5(d)). The absorption spectrum of the mixture at the molar ratios above $1: 1$ comprised the Soret band at $420 \mathrm{~nm}$ and also etio-type bands in the visible spectral region, which are typical of nonprotonated $\mathrm{TPPS}_{4}$ species.

\section{Discussion}

The factors determining formation of J-aggregates of $\mathrm{TPPS}_{4}$ molecules can be relatively divided into two groups: those being essential for the occurrence of the process and those affecting it either quantitatively or qualitatively. Summarizing the data of the extensive studies, the formation of J-aggregates in pure porphyrin solutions can be induced by lowering the value of $\mathrm{pH}$ below 3.5 and increasing the concentration of porphyrin above a certain level (typically $10^{-6} \mathrm{M}$ at $\mathrm{pH}=1$ ) [12]. This process can be modified by the presence of additional components in solution. Cations, cationic surfactants, and proteins were shown to faster and boost the aggregation under appropriate conditions $[14,15]$.

In the study on the interaction of TPPS $_{4}$ with HSA and $\beta$-lactoglobulin in acid media [15] it was reported that the formation of $\mathrm{TPPS}_{4} \mathrm{~J}$-aggregates and porphyrin-protein complexation depended on the protein nature, $\mathrm{pH}$, and the porphyrin/protein molar ratio. Our results suggest that the mechanism of $\mathrm{TPPS}_{4}$ interaction with protein can be affected not only by the above-mentioned factors but is also sensitive to the initial states of both interacting compounds. The spectroscopic changes (Fig. 4(a,b)) observed during the interaction of porphyrin with different amounts of protein in the acid medium were found to be strikingly different for lower $\left(5 \cdot 10^{-6} \mathrm{M}\right.$, Fig. 5(a)) and higher $\left(5 \cdot 10^{-5} \mathrm{M}\right.$, Fig. 5(b)) concentrations of $\mathrm{TPPS}_{4}$. Present data suggest an interaction scheme detailed below.

The amount of monomeric diprotonated species was significantly reduced in complex TPPS $_{4}$ solutions of lower porphyrin concentration, even by mixing stock solutions to get the small proportion of proteins to porphyrins. For BSA predissolved in acid (Figs. 4(a) and 5(b)) the interaction led to simultaneous formation of J-aggregates, the excitonic band of which was slightly blue-shifted relatively to that in a pure porphyrin solution. Submicromolar concentration of the protein (HSA) was suggested to support the positive microphase due to its global positive charge in the acid medium, and therefore, stimulating the formation of J-aggregates [15]. Similarly, BSA possesses global positive charge in acid media. We suggest that during the interaction proteins act as centres of condensation for monomeric $\left(\mathrm{H}^{+}\right)_{2}$ TPPS $_{4}$ species, thus facilitating the formation of J-aggregates on the surface of protein moiety. Similar surface-induced polymerization processes were reported for monomeric actin on a positively charged lipid monolayer [18]. High concentration of BSA disrupts these aggregates forming the protein-porphyrin complex absorbing at $421 \mathrm{~nm}$. Spectral properties of porphyrin species in this complex, especially those in the visible region, are typical of the neutral form of TPPS 4 implying that in the vicinity of BSA protons are released from the core of porphyrin ring (Fig. 5(b)). Deprotonation of TPPS $_{4}$ in acid media ( $\mathrm{pH}$ around 3.5) was also observed during the interaction of diprotonated species of $\mathrm{TPPS}_{4}$ with CTAB micelles [14].

J-aggregates prevailed in pure acid $\mathrm{TPPS}_{4}$ solutions at higher porphyrin concentration (Fig. 4(b)). When stock solutions were mixed together producing a small protein to porphyrin ratio, sudden appearance of the pellet was observed. The decrease in the intensity of the Soret band during this phenomenon was detected only at its short-waved side, where absorbance of aggregates is dominant. Higher BSA concentration, however, induced no precipitation in the complex solutions. We presume that the pellet was probably formed due to the strong interaction between J-aggregates boosted by protein molecules, which acted as centres of precipitation for aggregated porphyrins. A similar effect was reported in acid $\mathrm{TPPS}_{4}$ solutions in the presence of cationic surfactants [14]. The reason why higher protein concentrations prevented the formation of the pellet probably is that J-aggregates bound to proteins cannot interact so efficiently any more. The peak of 
the Soret band at around $423 \mathrm{~nm}$ evolved only at the highest BSA concentration implying the formation of a similar protein-porphyrin complex as that in the solution of lower TPPS 4 concentration. However, interaction with BSA was not efficient enough to disrupt most of those J-aggregates being already present in the pure $\mathrm{TPPS}_{4}$ solution.

While there are no marked changes observed in the absorption spectra of BSA solutions at different $\mathrm{pH}$ values (Fig. 3), the increase in medium acidity produces the distinct conformational changes of BSA. At $\mathrm{pH}=4$, albumin exists in the $\mathrm{F}$ form, which involves the unfolding of domain III $[19,20]$. At $\mathrm{pH}<4$, BSA undergoes another expansion with a loss of the intradomain helices of domains I and II. This expanded form is known as the E form [21]. The studies of $\mathrm{TPPS}_{4}$ interaction with BSA at different $\mathrm{pH}$ values revealed that different isomeric forms of albumin finally yield a complex with similar spectral features. However, various isomeric forms of protein can probably possess different affinity both to porphyrin and another protein molecules. This could explain the spectral differences observed during the interaction studies as reflected in Fig. 5.

Comparing the spectral changes induced by the interaction of $\mathrm{TPPS}_{4}$ with BSA predissolved either in acid (Fig. 5(b)) or in distilled water (Fig. 5(c)), one can note that in the latter case BSA had higher capacity for binding porphyrins. The amount of J-aggregates induced by BSA, which can be determined by the increased intensity of the J-band and its bathochromic shift in a complex solution, was found to be the highest at the smallest BSA concentration. Moreover, $\mathrm{J}$-aggregation was no longer favourable at higher BSA concentrations, which was not the case when BSA was predissolved in acid. Instead, the decrease in intensity of the J-band was accompanied by the rising peak of the Soret band at $421 \mathrm{~nm}$. The amount of J-aggregates formed in a complex solution by BSA predissolved in distilled water was lower than that observed by mixing both components predissolved in acid. Although, the spectral bands in the visible spectral region attributable to the deprotonated species of $\mathrm{TPPS}_{4}$ had the highest expression in the former case. However, even at these interaction conditions (porphyrin/protein molar ratio $1: 10$ ) BSA did not disrupt $\mathrm{J}$-aggregates formed in a pure acid TPPS $_{4}$ solution (Fig. 5(b)).

The albumins like many other molecules in solutions can form aggregated structures, especially at low $\mathrm{pH}$ [22]. We presume that BSA predissolved in distilled water is less aggregated in complex acid solu- tions and, therefore, demonstrates stronger interaction with monomeric $\left(\mathrm{H}^{+}\right)_{2} \mathrm{TPPS}_{4}$ form, thus preventing further formation of J-aggregates. On the other hand, BSA predissolved in acid is expected to have higher degree of aggregation in complex solutions. Those BSA molecules forming aggregates have reduced binding affinity to porphyrins. Nevertheless, such aggregates can probably serve as a template for the adsorbed porphyrin molecules assembling into J-aggregates on their surface.

\section{Conclusions}

From the above experimental results we come to the following conclusions. The pattern of the TPPS 4 interaction with BSA implies the concurrent mechanism. It depends on the relative concentrations of monomeric and aggregated species in a homogenous solution of TPPS $_{4}$ as well as on the initial state of a homogenous protein solution. Strong interaction with BSA shifts the Soret band of the formed TPPS $_{4}$-protein complex towards $421 \mathrm{~nm}$ independently of $\mathrm{pH}$. The high protein/porphyrin ratio leads to the formation of the TPPS 4 spectrum, typical of the deprotonated species of the porphyrin. The small relative concentration of the protein favours formation of J-aggregates of $\mathrm{TPPS}_{4}$, while higher concentration leads to their disruption. In complex acid solutions formation of J-aggregates is favoured by the higher aggregation of BSA. J-aggregates preformed in a homogeneous solution of TPPS 4 retain their spectral properties, adding protein does not disrupt these aggregates.

\section{Acknowledgement}

This study has been supported by the Lithuanian State Science and Education Foundation, project K-072.

\section{References}

[1] S.B. Brown and M. Shillcock, Biochem. J. 153, 278285 (1976).

[2] K. Uehara, Y. Hioki, and M. Mimuro, Photochem. Photobiol. 58, 127-132 (1993).

[3] C. Tanielian and G. Heinrich, Photochem. Photobiol. 61, 131-135 (1995).

[4] R.F. Khairutdinov and N. Serpone, J. Phys. Chem. 99, 11952-11958 (1995).

[5] D. Frolov, S. Bagdonas, L. Kelbauskas, W. Dietel, G. Streckytè, and R. Rotomskis, Lithuanian J. Phys. 41, 484-494 (2001). 
[6] D. Frolov, S. Bagdonas, R. Rotomskis, and V. Gulbinas, Lithuanian J. Phys. 40, 228-231 (2000).

[7] L. Kelbauskas, S. Bagdonas, W. Dietel, and R. Rotomskis, J. Lumin. 101, 253-262 (2003).

[8] M.A. El-Far and N.R. Pimstone, Cancer Res. 46, 4390-4395 (1986).

[9] M.A. El-Far, N.A. El-Hamil, and M. Ghoneim, Biochim. 70, 1379-1384 (1988).

[10] V.E. Yushmanov, T.T. Tominaga, I.E. Borissevitch, H. Imasato, and M. Tabak, Magn. Reson. Imaging 14, 255-261 (1996).

[11] J. Davila and A. Harriman, Photochem. Photobiol. 51, 9-19 (1990).

[12] O. Ohno, Y. Kaizu, and H. Kobayashi, J. Chem. Phys. 99, 4128-4139 (1993).

[13] D.L. Akins, H.-R. Zhu, and C. Guo, J. Phys. Chem. 98, 3612-3618 (1994).
[14] N.C. Maiti, S. Mazumdar, and N. Periasamy, J. Phys. Chem. B 102, 1528-1538 (1998).

[15] S.M. Andrare and S.M.B. Costa, Biophys. J. 82, 16071619 (2002).

[16] K. Berg and J. Moan, Int. J. Cancer 59, 814-822 (1994).

[17] S. Bagdonas and R. Rotomskis, Lithuanian J. Phys. 38, 75-78 (1998).

[18] A. Renault, P.-F. Lenne, C. Zakri, A. Aradian, C. Venien-Bruyan, and F. Amblard, Biophys. J. 76, 1580-1590 (1999).

[19] M.J. Geisowand and G.H. Beaven, Biochem. J. 163, 477-484 (1977).

[20] M.Y. Khan, Biochem. J. 236, 307-310 (1986).

[21] W.F. Harrington, P. Johnson, and R.H. Ottewill, Biochem. J. 62, 569-582 (1956).

[22] I.E. Borissevitch, T.T. Tominaga, H. Imasato, and M. Tabak, J. Lumin. 69, 65-76 (1996).

\title{
SAVITVARKIŲ TPPS ${ }_{4}$ NANODARINIŲ SPEKTROSKOPINIAI TYRIMAI: SAZVIKOS SU ALBUMINU IR APLINKOS pH ITAKA
}

\author{
J. Valančiūnaitė, J. Žerebcova, S. Bagdonas, G. Streckyte, R. Rotomskis \\ Vilniaus universitetas, Vilnius, Lietuva
}

\begin{abstract}
Santrauka
Vandeninèse rūgštinèse terpèse tetrapirolinis junginys mezotetra(4-sulfonatofenil)porfinas (TPPS 4 ) virsta jonine forma, kuri sudaro savitvarkius organizuotus mezodarinius - J agregatus. Nuostoviosios sugerties spektroskopijos būdu tirtos tụ agregatu susidarymo ypatybės jaučio serumo albumino įvairios koncentracijos ir skirtingo rūgštingumo tirpaluose. Nustatyta, kad vienodos TPPS $_{4}$
\end{abstract}

koncentracijos tirpaluose, priklausomai nuo terpès $\mathrm{pH}$ bei baltymo koncentracijos, susidaro skirtingas J agregatu kiekis. Porfirino joninès formos pusiausvirines sąveikas baltyminiuose tirpaluose lemia konkurencinis mechanizmas. Nedidelès baltymo koncentracijos skatino $\mathrm{J}$ agregatų susidarymą, tuo tarpu didesnès turejjo priešinga poveikį. Baltymas neturèjo įtakos jau susidariusių $\mathrm{J}$ agregatų patvarumui. 